\title{
Survival, Growth Strategies and Performance of Women Owned Micro and Small Businesses in Tanzania
}

\author{
Tundui, C. (Corresponding author) \\ Faculty of Social Sciences \\ Mzumbe University, Mzumbe, Tanzania \\ Tel: 255-754-825-860 E-mail: cstundui@mzumbe.ac.tz
}

Tundui, $\mathrm{H}$.

School of Business

Mzumbe University, Mzumbe, Tanzania

Tel: 255-718-664-215Ｅmail: htundui@yahoo.co.uk

Received: November 21, 2011

Accepted: March 23, 2012 Published: April 16, 2012

doi:10.5539/ijbm.v7n8p143

URL: http://dx.doi.org/10.5539/ijbm.v7n8p143

\begin{abstract}
This study examines the impact of survival and growth strategies adopted by the women micro and small business on performance of their enterprises. The data used in this study were obtained through a survey of 221 microcredit borrowers from PRIDE Microfinance program in Tanzania. The study uses logistic regression analysis to analyse the data. Study results have shown that among the growth strategies adopted by the owners, non-separation of business resources from household resources and ownership of multiple enterprises have a positive effect on enterprise profitability, while the use of unpaid family labour has a negative effect on enterprise profitability. Of the studied household and individual level variables, only household income; and business skills had a positive effect on enterprise performance. Taken together, these results suggest that intermingling of household and business resources; and household incomes were more important in the performance of women enterprises that are supported by microcredit.
\end{abstract}

Keywords: Survival, Strategies, Performance, Women, Micro and small business, Owners

\section{Introduction}

In the past two decades, Africa just like other developing countries has observed a progressive involvement of women in business ownership particularly in micro and small businesses in the informal sector. Their involve in business ownership has not only affected household economies and division of labour but also bears significant impact on the way African economies do business. For example, it is estimated that 92 per cent of women who are economically active outside of agriculture in Sub-Saharan Africa are micro and small business entrepreneurs in the informal sector (against 71 per cent for men) (Becker, 2004). Correspondingly, estimates in Tanzania show that women make up about 43 per cent of the total numbers of operators in the micro and small enterprises sector (Stevenson \& St-Onge, 2005).

Despite women's progressive involvement in business ownership, evidence suggests that women-owned businesses underperform businesses owned by men in a number of performance measures and are overrepresented in the sectors and activities that have a woman face (Stevenson \& St-Onge, 2005). Out of necessity, women select these activities because they do not require equity financing, extensive business experience and large amounts of initial capital (Ehlers \& Main, 1998). However, these activities have lower survival and growth rates because of competition in their markets and hence lower earnings potential (Coleman, 2007). Women businesses also operate at the "end" of the value chain (Brush \& Chaganti, 1999).

Research also notes that there are other factors constraining survival and growth of women businesses. Women, particularly, in Africa, start out their businesses with comparatively fewer resources than men and other women in the developing world. Similarly, their business operating environments are less supportive due to socio-cultural, economic factors and the general business environment forces that work against them (Marcucci, 
2001). Consequently, most of these activities suffer high mortality rates but also can hardly graduate to medium or large size. For example, UNCTAD (2006) estimates that on average, 50 percent of businesses in the continent fail in their first three years of operation and it is only 7 percent of the new micro enterprises that grow to the small and medium or large size.

In view of the constraints facing women, women entrepreneurs in Africa take a different approach to business entry, survival and the way they pursue business growth (Richardson et al., 2004). However, evidence from literature shows that there is scanty literature on the extent to which entry, survival and growth strategies adopted by the women business owners influence growth of their businesses.

Therefore, this article aims at providing empirical evidence from Tanzania of the extent to which business entry, survival and growth strategies adopted by the women influence growth of their businesses.

\section{Literature Review and Study Hypotheses}

Literature posits a number of business entry, survival and growth strategies that are usually adopted by the women micro and small business owners. Some of these strategies are discussed hereunder;

\subsection{Business entry, survival and growth strategies}

\subsubsection{Ownership of multiple enterprises}

Most of women entrepreneurial activities suffer from the liabilities of smallness and newness, but also face stiff competition. One possible avenue to stand the test of these challenges is to opt for diversified business activities that offer and lead to better chances of survival (Marcucci, 2001). Marcucci (2001) argues that diversification plays a significant role in women owned businesses: firstly, as a strategy for capital accumulation so that the enterprise can expand and specialize at a later time, secondly, as a way of spreading risks across a number of activities; and thirdly as a way of testing or identifying new market opportunities/niche. Similarly, ownership of multiple enterprises especially ones with seasonal markets and cash flow, opens up avenues for the business owner to take advantage of the pool of family resources, skills and experiences, and helps to ensure a constant flow of income for owners and their households (Richardson et al., 2004). Literature suggests that women in Africa grow their business differently from men. As a survival and growth strategy women tend to develop several businesses rather than focusing on the development of one business (ILO, 2004). However, critics contend that the ownership of multiple enterprises tends to over-stretch the business owner in terms of capability, time and resources across a number of different micro/small businesses (ILO, 2004). It is also argued that, ownership of multiple enterprises is likely to reduce the amount of owners' effort and commitment to the business due to competition over time, energy and other resources that the competing businesses place on the owner and other resources (Olson et al,. 2003).

Given that the sampled respondents in this study are microcredit borrowers, they are likely to use profits generated from other enterprises to support the activity that uses the loan fund, or assist with repaying the loan and thereby amplifying the impact of the loan fund on the performance of the enterprise that is supported by the loan fund. It is therefore hypothesized that:

\section{Ha: Ownership of multiple enterprises has a positive effect on enterprises performance}

\subsubsection{Intermingling (non-separation) of business and household resources}

Studies on micro and small businesses report that comparable to men, women are more likely to not separate their business resources from household resources with a view to improving both the welfare of their businesses and households (Haynes et al., 1999). In this respect, resources will flow to either side depending on where they have the least opportunity cost or maximum use value (Haynes et al., 1999).

In exploring the reasons for intermingling of business and household resources, Haynes, et al. (1999) find that intermingling of business and household resources is likely to be practised when the business owner is a sole proprietor and a borrower from financial institutions. In that regard, given that the majority of women are not propertied, they are likely not to separate their business resources from household resources to give them an advantage to use household resources as collateral. In particular, intermingling of business resources and household resources is practised as a survival and growth strategy; but also as a way of minimizing business operational costs (Haynes et al., 1999). Based on the discussion it is hypothesised that:

\section{$H b$ : Intermingling of business and household resources has a positive effect on business performance}

\subsubsection{Business location}

Geographic location of a business explains its life span, survival and growth (Abouzeedan \& Busler, 2004). 
Arguably, enterprise growth possibilities differ across locations due to differences in location's resource base and other advantages, for example, income of the population, availability of markets and labour (Sternberg \& Tamásy 1999). Location is also an important determinant of enterprise performance in the economies characterised by regional specializations (Elhiraika \& Nkurunziza, 2005).

Research reports that due to family responsibilities and as a survival strategy, women are more likely to locate and manage their businesses from home (Stevenson \& St-Onge, 2005). Women are also likely to locate their businesses at home to take advantage of household resources; or on event of constrained mobility or non-availability of proper business premises (Stevenson \& St-Onge, 2005). It is however, argued that micro and small businesses located at homes or owners' residence are less likely to survive and grow than businesses located in commercial areas (Mead \& Liedholm, 1998). Home based locations limit women's access to raw materials and markets because contacts with suppliers and customers are minimized. We hypothesise that:

\section{Hc: A home-based location has a negative effect on business growth}

\subsubsection{Sources of financing and enterprise capital structure}

Growth of any business irrespective of size depends on the amounts of capital acquired at business start-up and the amounts available for operational activities as well as for supporting enterprise expansion. The amount of capital available to the business can also influence its capital structure and profitability (Coleman, 2007). Financial capital can be in the form of debt and/or equity and other external sources (Coleman \& Carsky, 1999). For established businesses, retained earnings are the predominant source of financing among growing micro and small businesses (Papadaki \& Chami, 2002). Likewise, micro and small businesses that are more successful are likely to use more external sources of financing than less successful businesses (Papadaki \& Chami, 2002). It is however, suggested that the majority of micro and small business owners are reluctant to use external sources of financing because of high interest and fee rates charged to the recipients of loans (Papadaki \& Chami, 2002), risk aversion and fear of losing control of their businesses (Harvey \& Evans, 1995). Some business owners also dislike being in debt and the pressures of loan repayments (Orser et al., 2006). Hence, as an entry strategy, women are likely to depend largely on their own limited cash resources, families and friends for investment capital (Stevenson \& St-Onge, 2005). Nonetheless, relying largely on owners, family and friends financial resources may not meet the start-up needs of the business. It is predicted that:

Hd: The use of own sources of fund as seed capital has a negative effect on business growth.

\subsubsection{The use of unpaid family labour}

Studies on microcredit and micro enterprising have also shown that as a survival and growth strategy, micro and small women business owners who are microcredit borrowers are less likely to use paid employees in their businesses (Tundui \& Mgonja, 2010). Arguably, being confronted by the challenges of loan repayment pressures; microcredit borrowers may not employ paid employees who could increase demand on their enterprise's cash flow in terms of weekly and monthly wage bills. Instead, microcredit borrowers are oftentimes using unpaid family members to provide the needed labour supply requirements. However, the use of family members may lead to higher agency costs in case members of the family fail to monitor each other or when they lack the necessary skills and abilities and when they use business assets for personal use, thus draining the business of financial and other resources (Dyer, 2006). It is postulated that:

\section{He: The use of unpaid family labour has a negative effect on business growth.}

\section{Other factors}

Entrepreneurship research also shows that business growth is influenced by demographic characteristics of the entrepreneur and business characteristics including whether the business is formal or informal, micro, small or big (Marcucci, 2001). This is particularly the case in micro and small businesses where the key business decisions and success lie in the choices of the owner (Harvey \& Evans, 1995).

\subsection{Demographic characteristics of the business owner}

\subsubsection{Marital status}

Numerous studies on small business ownership find that marital status of an entrepreneur has an important effect on growth of women owned enterprises. For example, as a survival and growth strategy, married entrepreneurs especially those who are married to self-employed husbands can tap on the household income (financial), human and social capital resources owned by spouses (Caputo \& Dolinsky, 1998; Casson, 2005; Philbrick and Fitzgerald, 2007). In this respect, marriage increases the likelihood of women's involvement in business ownership, but also holds the possibility of enhancing growth potential of their businesses. 


\subsubsection{Age of the entrepreneur}

The age of the business owner represents the stocks of human, social and financial capital that enable individuals to start, operate a business and stand the test of periods of financial intricacy (Coleman, 2007). Similarly, older and more experienced business owners are more likely to make informed decisions because of lessons learned in the course of business operation (Headd, 2003). These views presuppose that older business owners are likely to experience enterprise growth than younger business owners.

\subsubsection{Education}

Entrepreneurs with higher education levels can effectively manage and succeed in their businesses (Barringer et al., 2005). This is especially the case when entrepreneurs start businesses related to their areas of expertise. Education also enhances entrepreneurs' self-confidence and capability to perceive and exploit new entrepreneurial opportunities (Verheul et al., 2001). Empirical evidence on the impact of education level on business growth in Africa, by Biggs and Shah (2006) shows that entrepreneurs with university or technical degrees start businesses approximately 50 per cent larger than entrepreneurs who have only attained primary education. Similarly, managers with secondary and university educations run MSEs that grow 6 per cent faster on average than MSEs with managers who have attained primary or no education. This suggests that better educated entrepreneurs are more likely to experience growth in their businesses than entrepreneurs with low levels of education.

\subsection{Business Characteristics, start-up reasons and business management experience}

\subsubsection{Business age}

Studies on small enterprise growth have also established that business age plays an important role in enterprise performance and growth. Empirical evidence from earlier studies for example, shows that there is a negative relationship between business growth, age and size. However, Jovanovich (1982) finds that while smaller and younger businesses grow faster than larger and older businesses, smaller and newer businesses on the other hand are less likely to survive than larger and older businesses. On the other hand, Papadaki \& Chami (2002) observed that among small businesses, older businesses grow faster than younger ones, and among larger businesses, growth declines with age.

Moreno and Cassilas (2007) argue that younger businesses grow faster than older businesses because of owners less understanding of their costs functions and willingness to take risks. By contrast, older businesses may not show significant growth changes when owners have achieved optimal sizes that allow them to maximize their levels of efficiency and resource combination that best meet their market demands.

Despite these conflicting views, given that the respondents in this study were micro credit clients who should start with small loan sizes and graduate to big loan sizes in the course of time, this implies that loan size increases with business age, thus amplifying the impact of the business age on enterprise performance.

\subsubsection{Business skills and experience}

Possession of relevant skills and experience helps ensure the survival of a business at start-up, its future performance and growth. This is especially the case for business skills and specific experience in similar businesses (Cooper et al., 1994). The skills and specific experience in a similar business also help owners build a growth-oriented business (Barringer et al., 2005).

\subsubsection{Start-up reasons}

Studies on entrepreneurial motivation posit a wide range of reasons for involvement in entrepreneurship; this is especially for women entrepreneurs. Bosma and Harding (2006) noted that on average, the majority of women are being pushed into entrepreneurship because of necessity resulting from the lack of other options available for sources of income. It is however argued that businesses started by individuals who have been pushed by the lack of alternative employment or other sources of income, push factors are likely to lead to less promising, low return and low growth potential ventures (Morris et al., 2006). This is because necessity entrepreneurs more often have limited business management experience and lack sufficient resources to start and run successful businesses (Andersson et al., 2007).

\section{Sample and Methodology}

Our study surveyed a random sample of 221 women entrepreneurs who have accessed micro loans from PRIDE - Tanzania microfinance program at Morogoro town branch. PRIDE Tanzania is the largest micro lender in Tanzania. To ensure that the reliability of study results is maintained, the main study was preceded by a pilot study. The pilot study was also carried out to help testing clarity and relevance of research instruments and 
methodology of the study in general, but also to test if the hypotheses, variables and measures were appropriate.

After the pilot study, preparations for the main study followed. These involved refinement of the questionnaire. In refining the questionnaire, the original questionnaire was shortened and questions that were found to be ambiguous were dropped. In addition, in refining the questionnaire, rephrasing and sequencing of questions were taken into account to ensure that all respondents have a common understanding of the questions. Refinement also took into account the time taken to complete the questionnaire.

Moreover, to avoid the problem of selection bias, clients were clustered based on their loan sizes and then were randomly selected from PRIDEs' list of clients. This is because the impact of microcredit on business performance is assumed to vary with loans size. This study involved the use of a cross-sectional design, which collects information at one point in time only. All those who were involved in the survey were owners of the enterprises. The survey was undertaken in September - October 2008. A profile of the sampled respondents and the types of their businesses is presented in Table 1.

\section{Enterprise performance and growth}

Profitability is one of the several measures used to determine performance and growth of an enterprise (Harber \& Reichel, 2005). While using enterprise profitability is the simplest way to assess business performance and growth, data on business profitability may not be readily available especially when owners are unwilling to provide specific information regarding financial performance of their businesses, poor record keeping (Wolff \& Pett, 2007) or failure to separate household resources use from business resources (Honig, 1998). Hartarska \& Gonzalez-Vega (2006) argue that one of the challenges faced when studying micro and small business performance is how to distinguish between business and household resources. These limitations make it difficult to measure micro and small-business performance and the use of sales revenue or profits lead to somewhat less accurate results and incorrect decisions.

Dependent variable: for the purpose of this article, and taking into account the above limitations, a qualitative measure of enterprise growth/performance was used. This measure required a respondent to state the status of her business profitability (sales revenue less all operating expenses or cost of sales) since joining the microfinance programme for the new clients (clients in the first loan cycle) and during the last six months (6) for the mature clients (clients in second or more loan cycle)s. Two scales were used for this purpose: business profits decreased and business profits increased. For the purpose of logistic regression analysis, if a business had experienced growth in profitability 1 (one) was used, and if otherwise, a value of 0 (zero) was assigned to the dependent factor.

Independent Variables: these include the variables representing entry, survival and growth strategies adopted by the business owners. Age, marital status, education, possession of business skills and experience; and business characteristics were used as control variables. Their coding and measurement are given in table 2.

\section{Correlation analysis}

To determine the extent to which entry, survival and growth strategies adopted by women business owners influence performance of their businesses; we first run correlation analysis among the predictors selected for this study. Correlation analysis was meant to determine how independent variables are correlated with the dependent variable but also to determine whether there could be a problem of multicollinearity among the independent variables.

Correlation analysis shows that non-separation of household resources from business resources $(r=0.40, p<0.01)$, ownership of multiple enterprises $(\mathrm{r}=0.21, \mathrm{p}<0.01)$ and household incomes $(\mathrm{r}=0.45, \mathrm{p}<0.01)$, are positively correlated with business profitability. These results may imply that owners who do not separate business resources from household resources use, those who own multiple enterprises and those who experienced increase in their household incomes were likely to experience growth in their businesses than otherwise.

It is also observed that loan size is positively correlated with business age $(r=0.62, p<0.01)$ and owners' age $(r=$ $0.21, \mathrm{p}<0.01)$. Possibly because, given that individual clients should start with a minimum loan size and graduate to higher loan categories in a course of time, it is obvious that loan size will tend to increase with both owners' age and business age. On the other hand, loan size is also negatively correlated with household income $(\mathrm{r}=0.29$ $\mathrm{p}<0.01)$. This suggests that household income is perhaps used to service the loan.

Largely, the correlation coefficients show that there is not high correlation among independent variables included in the analysis, and therefore any serious problem of multicollinearity among the variables is unlikely. Field (2005) posit that multicollineality is likely to be a problem in a data set if the correlation coefficient between predictors is greater than $0.90(\mathrm{r}>0.90)$. A correlation matrix for the study variables is given in Table 3 . 


\section{Multivariate analysis}

\subsection{Logistic regression analysis}

There are a number of alternative approaches to modelling dichotomous dependent variables, such as logistic regression, probit and discriminant function analysis. However, logistic regression is the most commonly used approach because of its flexibility and robustly to the violation of the normality assumptions (Cooper et al., 1994). Logistic regression also permits prediction of a dependent variable from a set of predictors that may be continuous, discrete, dichotomous, or a combination of any of these (Fabowale et al., 1995). On the other hand, while discriminant analysis can be used to model dichotomous dependent variables, the analysis is only used with continuous predictors (Fabowale et al., 1995). Given the nature of our data, we used logistic regression analysis to determine the extent to which each of the predictors influences enterprise performance (profitability).

\subsection{Results}

Table 4 presents the logistic regression analysis results for the business profitability. Results are presented and discussed in terms of the standardised beta coefficients. To test for the model fit and adequacy, Hosmer-Lemeshow test $\left(\mathrm{R}_{\mathrm{L}}^{2}\right)$ was used. According to the $\mathrm{R}_{\mathrm{L}}^{2}$ value, 68.0 per cent of the variance of enterprise profitability is explained by our data. These results also show that there is not high correlation among independent variables included in the analysis, and therefore any serious problem of multicollinearity among the variables is unlikely. Menard (2004) posits that multicollineality is likely to be a problem in a data set if the standardized beta coefficients are greater than one.

In logistic regression, the values of standard deviations are obtained from the predicted values of logit $(\hat{Y})$ (Menard, 2004). According to Menard (2004) a standardized coefficient is interpreted as one standard deviation change in the independent variable $(\mathrm{X})$ produces a $\beta^{*}$ standard deviation change in logit $(\hat{Y})$.

\subsubsection{Entry, survival and growth strategies}

Among the entry and survival strategies adopted by the business owners, only three variables have turned out to have a significant effect on enterprise profitability; ownership of multiple enterprises $(\beta=0.194, p<0.01)$ and intermingling of business and household resources $(\beta=0.412, p<0.01)$.

Results have also shown that the use of unpaid family labour in the business as a survival strategy is negatively predicting enterprise profitability $(\beta=-0.308, p<0.01)$. These results suggest that women entrepreneurs who use unpaid family labour in their enterprises are less likely to experience growth in business profitability as compared to those who do not use non family members or other paid employees.

Therefore, only hypotheses $H a$ and $H b$ that ownership of multiple enterprises, intermingling of business and household resources respectively have a positive effect on enterprise profitability are supported. Similarly hypothesis $\mathrm{He}$ that the use of unpaid family labour in the business has negative effect on business performance is supported. Hypotheses $H c$ and $H d$ that home-based business locations and the use of own sources of fund as a seed capital respectively have a negative effect on enterprise profitability could not be supported by our data.

\subsubsection{Individual and household level characteristics}

Among individual and household variables included in the analysis, only two variables have significant effect on business profitability. These are household income $(\beta=0.435, \mathrm{p}<0.01)$ and marital status $(\beta=0.193, \mathrm{p}<0.05)$. While the correlation results showed that marital status is not significantly correlated with enterprise profitability (Table 3), the logistic regression results show that marital status is negative and significantly predicting enterprise profitability, suggesting that its impact on enterprise profitability has been amplified by other factors in the model.

\subsubsection{Business characteristics and management experience}

Of the business characteristics and business management experience, only two variables are significantly predicting business profitability; possession of business skills related to business operations $(\beta=0.364, p<0.01)$ and the business age $(\beta=-0.274, p<0.05)$. The start-up reason has not turned out to have a significant effect on enterprise profitability, suggesting that start up reasons do not explain business profitability.

\section{Discussions}

The study provides evidence of the impact of entry, survival and growth strategies adopted by the women micro and small business owners on performance of their enterprises. It was also expected that access to micro credit would influence both enterprise profitability, and entry and survival strategies adopted by the business owners.

Our results have established that among the strategic choices made by the business owners, intermingling of 
household and business resources has a unique impact on enterprise profitability. Results show that women entrepreneurs who do not separate their business resources from household resources are more likely to experience enterprise profitability growth than those who separate their business resources from household resources. These results render support to previous research that non-separation of business resources from household resources enables women business owners to improve both the welfare of their households and their businesses (Haynes et al., 1999).

Similarly, results have shown that women business owners who have multiple enterprises are likely to experience business profitability growth as compared to women who have only one enterprise. These results contradict the general view that ownership of multiple enterprises has a negative impact on business growth (Richardson et al., 2004). However, these results should be interpreted with caution. Given that, the sampled respondents were micro credit clients, it is possible that the profits generated from other enterprises were used to fund the activity that uses the loan or assist with repaying the loan, thus, amplifying the impact of the loan on the business.

Moreover, while the use of family labour in the business is significantly predicting business profitability, its impact is negative. Dyer (2006) contends that this is likely to happen when the family members who are working in the businesses lack the required business skills and experience or are using business assets for their own personal use. This suggests that the use of unpaid family labour as a business survival and cost minimizing strategy is not always best for the business, but will depend on the type of skills possessed by members of the family and the conditions of their engagement.

Results have also demonstrated that the majority of women that experienced business profitability growth also experienced increase in their household's incomes. These results might suggest that performance and growth of women enterprises to some extent depend on the status of their household's income. These findings are consistent with prior research, suggesting that household incomes play a significant role in the performance and growth of women owned micro and small businesses (Allen et al., 2006). Specifically, studies on micro-credit impact assessment have indicated that the growth of women owned enterprises supported by micro credit depends on household conditions (income) and other household endowments (Khalily, 2004). Our results have also established that while household income is positively correlated with enterprise profitability $(r=0.450, p$ $<.01)$, it is negatively correlated with loan size $(\mathrm{r}=-0.290, \mathrm{p}<0.01)$ (Table 3). Perhaps, household income is being used to support business operations but also used to service the loan.

Possession of business skills and experience has a positive significant impact on business profitability. On the other hand, the effect of education on the enterprise performance is non-significant, probably because the majority of respondents had low levels of education to have a significant effect on enterprise profitability. These results also support previous studies that the majority of women micro and small business owners in Tanzania have low levels of education (Stevenson \& St-Onge, 2005).

Our study findings have also demonstrated that business profitability is negatively related to the business age. This implies that profit does not necessarily increase as the business becomes older or have access to larger loan sizes. In other words, younger businesses and businesses in smaller loan categories perform better than older businesses. Possibly, the new clients who are also likely to own younger businesses might have been motivated to work hard for their businesses to generate surplus for them to service the loans and support other business operations but also qualify for bigger or renewal of loans. This result also support previous research that younger businesses are more likely to exhibit enterprise growth than more mature businesses (Moreno \& Cassilas, 2007).

Further, results have demonstrated that marital status is negative and significantly predicting enterprise profitability. This shows that married entrepreneurs are less likely to experience growth in enterprise profitability as compared with other marital status categories. Possibly, for married women to function as entrepreneurs and wives, results in a role conflict in a household and as a result placing the enterprise at a stake. These results also render support to previous research that conflicting business and household/family responsibilities have a far reaching effect on women's than men's businesses (Morris, et al., 2006).

\section{Study and Policy Implications}

Of the entry, survival and management strategies adopted by women business owners, only non-separation of household resources from business resources and ownership of multiple enterprises have a significant impact on enterprise profitability. Similarly, some individual and household level factors, business characteristics and business management skills seem to have a significant effect on enterprise profitability. Nevertheless, in total, these variables explain 51.1 percent of variance in enterprise profitability, suggesting some other factors not included in the model account for this unexplained variance. These findings further imply that micro and small 
enterprise growth is a multi-dimensional aspect that is determined by myriad of variables, including, the individual owners, business and households characteristics; entry, survival and growth strategies adopted by the owners and the general business environment. Therefore, for informed decisions, policy measures designed to support and promote women entrepreneurship should be based on better understanding of women's household conditions, their coping strategies and the socio-economic conditions facing the women. Correspondingly, these measures should address the issues pertaining to entry and survival (growth) strategies adopted by women business owners to support their businesses' survival and growth.

\section{Limitations of the study, contribution to literature and future research}

Our study has focused on women business owners who are clients of a micro credit program. This may imply that strategies adopted by women business owners may have been influenced by their access to microcredit. It is therefore possible that the women entrepreneurs who are not members of micro credit programs will adopt different survival and growth strategies. Similarly, the survival and growth strategies adopted by the small business owners have contextual influences (Allen et al., 2006). Therefore, it is imperative that country contexts, such as the gender based socio-cultural factors are taken into account.

While our study findings add to the debate regarding the impact of the entry and survival strategies adopted by the women business owners on the performance of their businesses, the way these strategies translate into business profitability has not been addressed by this study. Therefore, future research could explore the way these strategies and household level factors and endowments translate into women owned enterprises' performance. Moreover, future research could explore the strategies adopted by the women who are not members of micro-credit programs.

\section{Conclusion}

This study examines the impact of the entry, survival and management strategies adopted by women on growth of their micro and small businesses. Study results have shown that growth of women enterprises in addition to entry and survival strategies adopted by the entrepreneur is also determined by individual and business characteristics. More importantly, the study found that among the growth strategies adopted by entrepreneurs, non-separation of business resources from household resources, ownership of multiple enterprises and the use of family labour have a significant positive effect on business profitability. The only household and individual level variables observed to have a positive significant effect on enterprise profitability are household incomes and possession of business skills respectively. On the other hand, the business age and marital status have a significant negative effect on enterprise profitability. These results suggest that non-separation of business resources from household resources and status of household incomes are more important in the growth of women owned enterprises that are supported by micro credit. The results also suggest that although access to micro credit may enable women to fund their enterprise operations, its impact on enterprise performance is mediated by other factors.

\section{References}

Abouzeedan, A., \& Busler, M. (2004). Typology Analysis of Performance Models of Small and Medium-Size

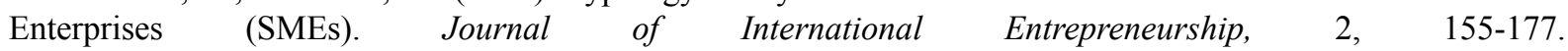
http://dx.doi.org/10.1023/B:JIEN.0000026911.03396.2d

Allen, E., Langowitz, N., \& Minniti, M. (2006). Global Entrepreneurship Monitor. London: Babson College.

Andersson, I., Raihan, A., Rivera, M., Sulaiman, I., Tandon, N., \& Welter, F. (2007). Handbook on Women-owned SMEs Challenges and Opportunities in Policies and Programmes. International Organisation of Knowledge Economy and Enterprise Development (IKED).

Arenius, P., \& Kovalainen, A. (2006). Similarities and Differences across the Factors Associated with Women's Self-employment Preference in the Nordic Countries. International Small Business Journal, 24(1), 31-59. http://dx.doi.org/10.1177/0266242606059778

Barringer, B., Jones, F., \& Neubaum, D. (2005). A quantitative content analysis of the characteristics of rapid-growth businesses and their founders. Journal of Business Venturing, 20(2005), 663-687. http://dx.doi.org/10.1016/j.jbusvent.2004.03.004

Becker, R. (2004). The informal Economy, The Fact Finding Study, SIDA. [Online] Available: http://rru.worldbank.org/Documents/PapersLinks/Sida.pdf (7th March 2012)

Biggs, T., \& Shah, M. (2006). African SMEs, networks, and manufacturing performance. World Bank Policy Research Working Paper No. 3885. World Bank, New York. 
Brush, C., \& Chaganti, R. (1999). Businesses without glamour? An analysis of resources on performance by size and age in small service and retail businesses. Journal of Business Venturing, 14, 233-257. http://dx.doi.org/10.1016/S0883-9026(97)00103-1

Caputo, R., \& Dolinsky, A. (1998). Women's choice to pursue self-employment: The role of financial and human capital of household members. Journal of Small Business Management, 36(3), 8-17.

Casson, M. (2005). The Individual - Opportunity Nexus: A Review of Scott Shane: A General Theory of Entrepreneurship. Small Business Economics, 24, 423-430. http://dx.doi.org/10.1007/s11187-004-5613-x

Coleman, S. (2007). The Role of Human and Financial Capital in the Profitability and Growth of Women-Owned Small Businesses. Journal of Small Business Management, 45(3), 303-319. http://dx.doi.org/10.1111/j.1540-627X.2007.00214.x

Coleman, S., \& Carsky, M. (1999). Sources of Capital for Small Family- Owned Businesses: Evidence from the National Survey of Small Business Finances. Family Business Review, XII, No. 1(March).

Cooper, A., Gimeno-Gacson, F., \& Woo, C. (1994). Initial Human and Financial Capital as Predictors of New Venture Performance. Journal of Business Venturing, 9, 371-395. http://dx.doi.org/10.1016/0883-9026(94)90013-2

Ehlers, T., \& Main, K. (1998). Women and false promise of micro-enterprise. Gender and Society, 12(4), 424-440. http://dx.doi.org/10.1177/089124398012004004

Elhiraika, A., \& Nkurunziza, J. (2006). Facilitating Business Entry, Growth and Survival with Special Attention to SMEs. ATPC Work in Progress No. 46, Economic Commission for Africa (November).

Fabowale, L., Orser, B., \& Riding, A. (1995). Gender, structural factors, and credit terms between Canadian small businesses and financial institutions. Entrepreneurship Theory and Practice, 19(4), 41-65.

Field, A. (2005). Discovering Statistics Using SPSS. ( ${ }^{\text {nd }}$ Ed). London: SAGE Publications.

Harber, S., \& Reichel, A. (2005). Identifying Performance Measures of Small Ventures-The Case of the Tourism Industry. Journal of Small Business Management, 243(3), 257-286.

Hartarska, V., \& Gonzalez-Vega, C. (2006). What affects new and established businesses' investment: Evidence from small businesses in Russia. Small Business Economics Journal, 27(2-3), 195-206. http://dx.doi.org/10.1007/s11187-006-0012-0

Harvey, M., \& Evans, R. (1995). Strategic windows in the entrepreneurial process. Journal of Business Venturing, 10, 331-347. http://dx.doi.org/10.1016/0883-9026(95)00037-9

Haynes, G., Walker, R., Rowe, B., \& Hong, G. (1999). The intermingling of business and family finances in family-owned businesses. Family Business Review, 12 225-239. http://dx.doi.org/10.1111/j.1741-6248.1999.00225.x

Headd, B. (2003). Redefining Business Success: Distinguishing Between Closure and Failure. Small Business Economics, 21, 51-61. http://dx.doi.org/10.1023/A:1024433630958

Honig, B. (1998). What Determines Success? Examining the Human, Financial, And Social Capital of Jamaican Micro entrepreneurs. Journal of Business Venturing, 13, 371-394. http://dx.doi.org/10.1016/S0883-9026(97)00036-0

ILO. (2002). Women and Men in the Informal Economy: A Statistical Picture. Gender and Employment Sector, ILO, Geneva.

ILO. (2004). A Fair Globalization: Creating Opportunities for All, ILO, Geneva.

Jovanovich, B. (1982). Selection and Evolution of Industry. Econometrica, 50(3), 649-670. http://dx.doi.org/10.2307/1912606

Khalily, M. (2004). Quantitative Approach to Impact Analysis of Microfinance Programmes In Bangladesh-What Have We Learned. Journal of International Development, 16, 331-353. http://dx.doi.org/10.1002/jid.1081

Marcucci, P. (2001). Jobs, Gender and Small Enterprises in Africa and Asia: Lessons Drawn from Bangladesh, the Philippines, Tunisia and Zimbabwe. SEED Working Paper 2001/18, WEDGE series, 2001.

Mead, D., \& Liedholm, C. (1998). The Dynamics of Micro and Small Enterprises in Developing Countries. World Development, 26, 61-74., http://dx.doi.org/10.1016/S0305-750X(97)10010-9 
Menard, S. (2004) Six Approaches to Calculating Standardized Logistic Regression Coefficients. The American Statistician, 58(3). http://dx.doi.org/10.1198/000313004X946

Moreno, A., \& Casillas, J. (2007). High-growth SMEs versus non-high-growth SMEs: a discriminant analysis. Entrepreneurship and Regional Development, 19, 69-88. http://dx.doi.org/10.1080/08985620601002162

Morris, M., Miyasaki, N., Watters, C., \& Coombes, S. (2006). The Dilemma of Growth: Understanding Venture Size Choices of Women Entrepreneurs. Journal of Small Business Management, 44(2), 221-244. http://dx.doi.org/10.1111/j.1540-627X.2006.00165.x

Olson, A., Patricia D., Virginia S., Zuikera, S., Danesa, K., Ramona K., \& Duncand, K. (2003). The impact of the family and the business on family business sustainability. Journal of Business Venturing, 18, 639-666. http://dx.doi.org/10.1016/S0883-9026(03)00014-4

Orser, B. J., Riding, A. L., and Manley, K. (2006). Women Entrepreneurs and Financial Capital. Entrepreneurship Theory and Practice, 30, 643-665. http://dx.doi.org/10.1111/j.1540-6520.2006.00140.x

Papadaki, E., \& Chami, B. (2002). Growth Determinants of Micro-Businesses in Canada, Ottawa: Industry Canada, Small Business Policy Branch (July). [Online] Available: http://www.ic.gc.ca/eic/site/sbrp-rppe.nsf/eng/h_rd01522.html (September 28, 2010)

Philbrick, C., \& Fitzgerald, M. (2007). Women in Business-owning Families: a Comparison of Roles, Responsibilities and Predictors of Family Functionality. Journal of Family and Economic, 28, 618-634.

Richardson, P., Howarth, R., \& Finnegan, G. (2004). The Challenges of Growing Small Businesses: Insights from Women Entrepreneurs in Africa. ILO Geneva.

Sternberg, R., \& Tamásy, C. (1999) Munich as Germany's No. 1 High Technology Region: Empirical Evidence, Theoretical Explanations and the Role of Small Business/Large Business Relationships. Regional Studies, 33(4), 367-377. http://dx.doi.org/10.1080/713693560

Stevenson, L., \& St-Onge, A. (2005). Support for Growth-oriented Women Entrepreneurs in Tanzania. ILO, Geneva.

Tundui, C. S., \& Mgonja, B. E. (2010). Microcredit and Poverty alleviation through the Labour Market: Evidence from Women Microcredit Clients in Tanzania. Global Journal of Human Social Sciences, 10(2).

UNCTAD. (2006). The Least Developed Countries Report 2006, Geneva.

Verheul, I., Wennekers, S., Audretsch, D., \& Thurik, R. (2001). An eclectic theory of entrepreneurship: policies, institutions and culture. Tinbergen Institute Discussion paper no. TI 2001-030/3.

Wolff, J., \& Pett, T. (2007). Small-Firm Performance: Modelling the Role of Product and Process Improvements. Journal of Small Business Management, 44(2), 268-284. http://dx.doi.org/10.1111/j.1540-627X.2006.00167.x 
Table 1. Demographic and business characteristics, Entry, survival and growth strategies

\begin{tabular}{|c|c|c|}
\hline Characteristics & Frequency & Percentage \\
\hline \multicolumn{3}{|l|}{ Owners' Age } \\
\hline $18-25$ & 20 & 9.0 \\
\hline $26-35$ & 85 & 38.5 \\
\hline $36-45$ & 72 & 32.6 \\
\hline $46-55$ & 35 & 15.8 \\
\hline $56-65$ & 6 & 2.7 \\
\hline Over 65 & 3 & 1.4 \\
\hline \multicolumn{3}{|l|}{ Education level } \\
\hline No schooling & 13 & 5.9 \\
\hline Primary & 153 & 69.2 \\
\hline Secondary & 54 & 24.4 \\
\hline First degree & 1 & .5 \\
\hline \multicolumn{3}{|l|}{ Marital Status } \\
\hline Married/living together & 114 & 51.6 \\
\hline Widowed & 21 & 9.5 \\
\hline Separated/divorced & 32 & 14.5 \\
\hline Single/never married & 54 & 24.4 \\
\hline \multicolumn{3}{|l|}{ Business start- up reasons } \\
\hline Economic necessity & 142 & 64.3 \\
\hline Achievement & 46 & 20.8 \\
\hline Availability of entrepreneurial opportunities & 33 & 14.9 \\
\hline \multicolumn{3}{|l|}{ Business age } \\
\hline Less than one year & 74 & 33.5 \\
\hline $1-5$ years & 101 & 45.7 \\
\hline $6-10$ years & 38 & 17.2 \\
\hline Over 10 years & 8 & 3.6 \\
\hline \multicolumn{3}{|l|}{ Business location } \\
\hline Owner's residence & 76 & 34.3 \\
\hline Away from owners' residence & 88 & 39.8 \\
\hline \multicolumn{3}{|l|}{ Business experience and management practices } \\
\hline Business skills & 59 & 26.7 \\
\hline Intermingling of household and business resources & 102 & 46.2 \\
\hline Ownership of multiple enterprises & 108 & 48.9 \\
\hline Use of unpaid family labour & 183 & 82.8 \\
\hline \multicolumn{3}{|l|}{ Source of seed capital } \\
\hline Loan from friends or family & 26 & 11.8 \\
\hline Loan from PRIDE and other MFIs & 35 & 15.8 \\
\hline Use of own savings as seed capital & 96 & 43.4 \\
\hline
\end{tabular}


Table 2. Description of Variables and their measurement

\begin{tabular}{|l|l|l|l|}
\hline & $\begin{array}{l}\text { Variable } \\
\text { label }\end{array}$ & Variable Description & Variable measurement/Coding \\
\hline 1 & Loansize & Amount of last loan & Ln \\
\hline 2 & Ownage & Own age & Ln \\
\hline 3 & Owneduc & Own education & $1=$ Post primary, $0=$ otherwise \\
\hline 4 & Marstat & Marital status & $1=$ married, $0=$ otherwise \\
\hline 5 & H.income & Household income & $1=$ Increased, $0=$ otherwise \\
\hline 6 & Motives & Start-up reasons & $1=$ Necessity, $0=$ otherwise \\
\hline 7 & Busage & Business age(in months) & Ln \\
\hline 8 & Buskills & Possession of business skills & $1=$ Yes, $0=$ otherwise \\
\hline 9 & Multienterp & Ownership of multiple enterprises & $1=$ Yes, $0=$ otherwise \\
\hline 10 & Interming & $\begin{array}{l}\text { Intermingling of business and household } \\
\text { resources }\end{array}$ & $1=$ Yes, $0=$ otherwise \\
\hline 11 & Blocat & Business location away from home & $1=$ Yes, $0=$ otherwise \\
\hline 12 & Seedcap & Source of seed capital & $1=$ Own savings, $0=$ otherwise \\
\hline 13 & Flabour & Use of unpaid family labour in the business & $1=$ Yes, $0=$ otherwise \\
\hline
\end{tabular}

Table 3. Correlation Matrix for Key Study Variables

\begin{tabular}{|c|c|c|c|c|c|c|c|c|c|c|c|c|c|c|c|}
\hline$\#$ & Variable & 1 & 2 & 3 & 4 & 5 & 6 & 7 & 8 & 9 & 10 & 11 & 12 & 13 & 14 \\
\hline 1 & Profitability & 1 & & & & & & & & & & & & & \\
\hline 2 & Loansize & $-0.19 * *$ & 1 & & & & & & & & & & & & \\
\hline 3 & Owner age & -0.04 & 0.13 & 1 & & & & & & & & & & & \\
\hline 4 & Education & 0.13 & -0.04 & -0.08 & 1 & & & & & & & & & & \\
\hline 5 & Maristatus & -0.02 & -0.05 & -0.09 & 0.02 & 1 & & & & & & & & & \\
\hline 6 & H.income & $0.45^{* *}$ & $-0.29 * *$ & -0.09 & 0.09 & 0.06 & 1 & & & & & & & & \\
\hline 7 & Motives & 0.07 & -0.03 & 0.00 & -0.04 & -0.01 & 0.10 & 1 & & & & & & & \\
\hline 8 & Busage & $-0.18^{* *}$ & $0.62 * *$ & $0.21 * *$ & -0.03 & -0.05 & $-0.17 *$ & 0.101 & 1 & & & & & & \\
\hline 9 & Buskills & $0.21 * *$ & -0.019 & -0.05 & -0.01 & -0.01 & -0.01 & 0.00 & -.04 & 1 & & & & & \\
\hline 10 & Mutlienterp & $0.22 * *$ & -0.13 & 0.010 & 0.12 & 0.09 & 0.04 & 0.05 & -0.03 & 0.09 & 1 & & & & \\
\hline 11 & Interming & $0.40 * *$ & -0.12 & -0.07 & 0.08 & 0.09 & $0.32 * *$ & 0.05 & 0.01 & -0.02 & 0.11 & 1 & & & \\
\hline 12 & Buslocat & -0.03 & -0.03 & $-0.14 *$ & -0.03 & -0.03 & -0.011 & -0.06 & -0.07 & 0.02 & -0.12 & -0.09 & 1 & & \\
\hline 13 & Flabour & $-0.34 * *$ & $-0.17 *$ & -0.07 & 0.01 & -0.03 & -0.10 & -0.04 & -0.11 & -0.01 & -0.06 & $-0.24 * *$ & 0.00 & 1 & \\
\hline 14 & Seed cap & 0.03 & -0.00 & -0.09 & 0.01 & 0.00 & 0.07 & -0.07 & -0.01 & 0.05 & -0.00 & 0.10 & 0.08 & 0.00 & 1 \\
\hline
\end{tabular}


Table 4. Logistic regression results with enterprise profitability as a dependent variable

\begin{tabular}{|c|c|c|c|c|}
\hline \multirow{2}{*}{\multicolumn{3}{|c|}{ Variable Lable }} & B & $\mathrm{B}^{*}$ \\
\hline & & & & \\
\hline \multicolumn{3}{|c|}{ Loan size } & -0.022 & -0.005 \\
\hline \multicolumn{5}{|c|}{ Individual and household characteristics } \\
\hline \multicolumn{3}{|c|}{ Owner's age } & 0.142 & 0.011 \\
\hline \multicolumn{3}{|c|}{ Owners' education } & 0.923 & 0.121 \\
\hline \multicolumn{3}{|c|}{ Marita status } & -1.268 & $-0.193 *$ \\
\hline \multicolumn{3}{|c|}{ Household income } & 2.981 & $0.435 * * *$ \\
\hline \multicolumn{5}{|c|}{ Business characteristics and management experience } \\
\hline \multicolumn{3}{|c|}{ Business start-up reasonse } & 0.202 & 0.030 \\
\hline \multicolumn{3}{|c|}{ Business age } & -0.775 & $-0.274 * *$ \\
\hline \multicolumn{3}{|c|}{ Business skills \& experience } & 2.697 & $0.364 * * *$ \\
\hline \multicolumn{5}{|c|}{ Entry and survival strategies } \\
\hline \multicolumn{3}{|c|}{ Ownership of multiple enterprises } & 1.27 & $0.194 *$ \\
\hline \multicolumn{3}{|c|}{ Intermingling of business and household resources } & 2.704 & $0.412 * * *$ \\
\hline \multicolumn{3}{|c|}{ The use of own savings as seed capital } & -0.628 & -0.095 \\
\hline \multicolumn{3}{|c|}{ Business location away from owners' residence } & 0.282 & 0.042 \\
\hline \multicolumn{3}{|c|}{ Use of unpaid family labour in the business } & -2.032 & $-0.308^{* * *}$ \\
\hline \multicolumn{3}{|c|}{ Model Constant } & 2.431 & \\
\hline \multirow[t]{7}{*}{$\dagger$} & \multicolumn{2}{|c|}{$\mathrm{N}=221$} & & \\
\hline & \multicolumn{2}{|c|}{$* \quad \mathrm{p}<0.050$} & & \\
\hline & \multicolumn{2}{|c|}{ ** $\quad \mathrm{p}<0.010$} & & \\
\hline & \multicolumn{2}{|c|}{ *** $\quad \mathrm{p}<0.001$} & & \\
\hline & \multicolumn{4}{|c|}{ Model Constant 0.612} \\
\hline & \multicolumn{4}{|c|}{ Standard deviation of the logit $(\hat{Y})$ for the model $=2.233$} \\
\hline & \multicolumn{2}{|c|}{$\beta *=$ Standardized beta coefficient } & & \\
\hline
\end{tabular}

Standard beta coefficient is given as $\beta^{*}=(\beta)\left(\mathrm{S}_{\mathrm{X}}\right)(\mathrm{R}) /$ Slogit $(\hat{\mathrm{Y}})$

Where $\beta^{*}=$ full standardised logistic regression coefficients

$\beta=$ unstandardised logistic regression coefficients

$\mathrm{S}_{\mathrm{X}}=$ standard deviation of an independent variable

$\mathrm{R}=$ the correlation efficient

Slogit $(\hat{Y})=$ Standard deviation of logit 